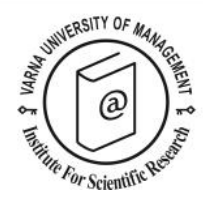

\title{
Exploring the effect of push and pull motivation factors on destination satisfaction: Empirical evidence from amenity migration perspectives
}

\section{Engin Unguren $^{1 *}$, Ömer Akgün Tekin² and Mehmet Bayırlı ${ }^{3}$}

\footnotetext{
${ }^{1}$ Faculty of Management, Alanya Aladdin Keykubat University, Alanya, Turkey. E-mail: engin.unguren@alanya.edu.tr

${ }^{2}$ Manavgat Tourism Faculty, Akdeniz University, Manavgat, Turkey. Email: dr.omerakguntekin@gmail.com 3 Faculty of Management, Alanya Aladdin Keykubat University, Alanya, Turkey. E-mail:

mehmet.bayirli@alanya.edu.tr

* Corresponding author
}

\begin{abstract}
This study was carried out within the context of amenity migration addressed as a category of post-tourism movements group with a purposeful sample of 489 participants. The main purpose of this research is to explore the motivations of participants of different nationalities in Alanya by using a push and pull framework and to investigate the relationship between motivation and overall destination satisfaction. A quantitative research methodology was adopted, and the descriptive and explanatory research methods were used. The findings of this study indicated that pull and push motivations of participants differ according to country origin. Furthermore, the results revealed that push and pull motivations significantly influence destination satisfaction. Moreover, it was concluded that push motivation factors of Middle Eastern and Russian participants had a higher impact on destination satisfaction than European participants. Findings of the research were discussed along with their theoretical contributions and managerial implications.
\end{abstract}

Keywords: Push and pull motivations, amenity migration, destination satisfaction, market segmentation, settlement patterns

Citation: Unguren, E., Tekin, O.A. and Bayırl, M. (2021). Exploring the effect of push and pull motivation factors on destination satisfaction: Empirical evidence from amenity migration perspectives. European Journal of Tourism Research 28, 2811 . 


\section{Introduction}

The concept of international migration has had a major impact on societies around the globe (Massey et al., 1993), and it appears that it will go on to have further effects. In this context, there has been a significant rise in the number of empirical studies on international migration. One of the types of international migration is amenity migration, which has been experienced since the Second World War. It is a type of migration that is carried out to benefit from sociocultural and economic opportunities, as well as to relieve stress in the environment that individuals experience (Borsdorf, Hidalgo, \& Zunino, 2012). Socioeconomic reforms and improvements in working life after the Second World War had consequences that made it easier for people to settle in other countries. At the same time as the retirement length increased as a result of increased life expectancy (Commission of the European Communities, 1994), the increase in retirees' savings in proportion to the improving economic conditions enabled individuals to prepare new strategies for their retirement (Williams, King, Warnes, \& Patterson, 200o) and even opened up the way for retirees to continue their lives in areas that offered better environmental conditions (Rodriguez, Mayorales, \& Rofo, 1998).

Amenity migration also can be considered as a subcategory of the post-tourism movements (Bourdeau, 2008). In tourism and migration studies, the pull and push motivation model is accepted as the dominant paradigm (Bansal, Taylor, James, 2005; Stimson \& Minnery, 1998). The motivation factors of individuals who prefer a destination within the scope of amenity migration and the motivation factors of tourists who prefer the same destination for holiday purposes may be similar (Ruiz-Ballesteros \& Caceres-Feria, 2016). Most people in both cases; is happy to be in places with natural, historical, cultural or attractions. One of the ways to achieve this is to go to these areas as a tourist. The other way is to live a longer life in these places with amenity migration. In fact, amenity migration has been conceptualized as "long-stay tourism" in some studies (Kummaraka \& Jutaporn, 2011; Ono, 2008; Stedman, Goetz \& Weagraff, 2006). This fact clearly affirms the close relationship between amenity migration and tourism. Also, it is known that tourist destinations are preferred for amenity migration in the future. Thus, visits to tourism destinations have seen as an effective factor in deciding on amenity migration (Williams et al., 2000). Satisfaction with holiday experiences significantly affects the revisiting of these destinations. (Kozak \& Rimmington, 200o). These repeat visits to tourism destinations may lead to the decision to acquire a second residence there (Breuer, 2005; Williams et al., 2000). This may cause tourism destinations to become amenity migration destinations over time.

The knowledge and experience gained with mass tourism after the 1950s, with the discovery of new habitats and the acquisition of secondary housing in these areas, laid the groundwork for an international migration of prosperity with a point of origin in tourism (Williams et al., 200o). The Mediterranean coast, in particular, has become an important secondary housing center due to factors such as hot climate conditions and rural and calm conditions compared to the crowded and industrialized cities in Europe. These secondary dwellings have also laid the groundwork for the start of international amenity migration over time (Gustafson, 2013; King, Warnes, \& Williams, 200o). This mobility has gradually established the destinations of amenity migration along the Mediterranean coast (Gustafson, 2008; Mason, 2002).

Turkey has been included in the list of countries that are frequently preferred by foreigners in the purchase of secondary housing, as well as Spain, Italy, and Portugal, as of the 2000 (Özerim, 2012). King et al., (2019) stated that international retirement migrations listed under amenity migration have shifted from destinations such as Spain and the southwest of France, which are traditional destinations, to new destinations, superseding traditional destinations. Many of the traditional destinations have become "saturated" with lifestyle and retirement migrants, with property prices increasing as a result. Thus, 
countries such as Turkey, Morocco, Thailand, and Malaysia have become preferred countries for international retirement migrations (King, Cela, Morettini, \& Fokkema, 2019).

This study was carried out in Alanya, one of the most important destinations in Turkey's tourism context. Alanya is one of the most important touristic regions of Turkey with its natural, historical, cultural, and gastronomic attractions (MasterCard, 2019). On the other hand, with its temperate climate conditions, improved economic opportunities, and multicultural structure, it is also a destination that has an important appeal for amenity migration. Alanya provides about $12 \%$ of Turkey's tourism revenues. Meanwhile, a total of 6,186 people from 74 countries purchased real estate in Alanya in 2018. To date, 42,882 people from 90 countries have purchased real estate in Alanya, including 2019. In 2018, a total of 20,619 people from 112 countries obtained residence permits for Alanya (ALTSO, 2019). In short, Alanya is an important destination for both tourism and amenity migration in Turkey and the Mediterranean region. To this end, there are three main objectives of the research. The first objective was to explore amenity migrants' motivations within the push and pull motivation framework. The study was focused on multiple nationalities. In this context, the second objective of the study was to determine important pull and push motivation factors by nationality. The third objective was to determine the effect of the pull and push motivations on overall destination satisfaction depending on the country of origin. In Turkey and other countries, a large number of studies have been carried out to determine tourists' travel motivations and vacation satisfaction. However, despite the increasing number of foreigners settling in Alanya and purchasing housing in the context of amenity migration, no empirical research has been conducted to determine the motivational factors or the relationship between motivational factors and destination satisfaction, which influence the decisions of foreigners settling in Alanya. In terms of destination management and tourism marketing, it is very important to determine the factors that influence tourists' choice of destination (Hsu, Tsai, \& Wu, 2009). Motivation is defined as a driving force behind behavior that leads an individual to specific activities (Mook, 1996; Moutinho, 2000). It is necessary to understand the reasons for which individuals are migrating in order to fully understand the phenomenon of amenity migration in this respect. The study of the push and pull factors of amenity migration and destination satisfaction within the framework of country of origin is one of the unique aspects of this research. On the other hand, the analysis of destination satisfaction within the framework of push and pull factors will also provide practical information about the satisfaction of individuals participating in amenity migration to Alanya. The results of the study will guide decision-makers on destination marketing and policymakers and businesses operating in the real estate and housing sectors in their decisions on marketing, product, and service developments.

\section{Conceptual Framework}

\section{Amenity Migration}

Amenity migration is a new type of migration that individuals with high levels of wealth do voluntarily to places where they think they will lead a better life (Benson \& O'Reilly, 2009; Borsdorf et al., 2012; Moss, 2006; Spalding, 2013; Südaş \& Mutluer, 2010). The concept of amenity migration is discussed under different concepts in different disciplines in the literature. Basically, most of the studies on "amenity migration" have been examined under the concepts of international retirement migration (Carlson et al., 1998; Cuba, 1991; Haas \& Serrow, 1993; Hazelrigg \& Hardy, 1995). The concept of amenity migration is also referred to as "lifestyle migration" (Benson \& O’Reilly, 20o9; Curry, Koczberski, \& Selwood, 2001; McIntyre, 2009; Mitchell, 2004), "second residence” (Hall \& Müller, 2004; Pitkänen, 2008), and "long-stay tourism" (Kummaraka \& Jutaporn, 2011; Ono, 2008; Stedman et al., 2006) by different scholars. 
Amenity migration started to develop mass tourism activities (Williams et al., 2000). Tourism is related to amenity migration from another perspective (Sanchez, 2017). According to Hall and Williams (2002), there are two basic forms of tourism and immigration relationship: (1) consumption-led tourism migrations (e.g., retirement second home ownership). In this form, individuals settle in areas of high attraction, such as beaches and mountainous regions. (2) production-led tourism migration. In this form, individuals migrate to tourism regions to work or establish a business. In this study, we focused on amenity migration which is an example of consumption-led tourism migration in Hall and Williams's (2002) classification. The psychological and emotional attraction created by the possibilities of a city affects the desire of individuals to be in that city temporarily or permanently. People can visit these areas temporarily as tourists, or they can plan to establish a settled life (Kuentzel \& Ramaswamy, 2005). On the other hand, touristic visits to these regions have an impact on the amenity migration decision. Therefore, tourism activity can be considered as the first stage of the amenity migration process (Nam \& Sato, 2010). According to Borsdorf, Hidalgo and Zunino (2012) amenity migration process usually starts with a touristic trip to the region to immigrate. In line with this view, Stewart (2002) explained the process that started with tourism and ended with amenity migration in five stages: (1) Initial visit to area, (2) Repeat visits, (3) Rent a cottage, (4) Buy a second home (5) Migrate.

The first amenity migrations in Europe started to take place from the cold northern countries of Europe to the warm southern countries, and over time, various destinations emerged in the southern countries of Europe (Gustafson, 2008; Mason, 2002). Remarkable and comprehensive studies on migration started to be carried out, especially in countries with a coast on the Mediterranean, after 1990 (King et al., 1998; Rodriguez et al., 1998; Warnes, King, Williams, \& Patterson, 1999; Williams, King, \& Warnes, 1997). On the European continent, countries bordering the Mediterranean such as Spain, Portugal, Italy, France, Greece, Croatia, and Turkey are among the popular countries in terms of amenity migration (Balkir \& Kirkulak, 2007; Hoggart \& Buller, 1995; King et al., 1998). There is a basic motivation of achieving more prosperous conditions in every sense at the basis of amenity migration (Sunil, Rojas, \& Bradley, 2007). Persons within the scope of amenity migration migrate to another region of their own will, temporarily or permanently, without any obligation.

This study was carried out in Alanya, one of the most important destinations in Turkey's tourism context. The tourism sector has been the driving force of the Alanya economy. Alanya is also one of the major attraction center of amenity migration in Turkey. 42,882 people from 90 countries have bought houses in Alanya since the 9o's (ALTSO, 2019). The phenomenon of amenity migration in Alanya dates to the early 1990s. After 1980, German tourists started to come to Alanya every year for holiday purposes and the number of tourists increased every year. German tourists got to know the city and local culture more closely as a result of their repetitive touristic trips to Alanya and started to buy secondary residences as of the second quarter of the 1990s. During this period, the city was nicknamed "Little Germany" and a TV series was broadcast under the name of "Germany-Alanya" on a national channel. Over time, people from different nations have bought housing in Alanya and have started to live in the region full time and periodically. In 2004, a foreigners' council was established within Alanya Municipality in order to find solutions to the problems of foreigners, to organize cultural, social and many activities. Also, foreigners living in Alanya have established churches for religious worship and opened businesses in many areas such as restaurants, bakeries, cafeterias and real estate agencies. In addition, special cemeteries were created by the municipality for foreigners in Alanya to carry out burials within the framework of their own beliefs. Alanya received foreign immigration from Scandinavian countries (Denmark, Norway, Sweden, Finland) in the early 200os, from Russia since the middle of 2000, and finally from Iran and Arab countries after 2010 similar to German welfare immigration in the 1990 s. 


\section{Motivation Factors of Amenity Migration}

Motivation is briefly described as a driving force behind behavior that leads an individual to specific activities (Mook, 1996; Moutinho, 2000). Therefore, the concept of motivation in tourism and travel research has been one of the most frequently used concepts to understand tourist behavior. Theories are developed and empirical studies are carried out within the framework of the concept of motivation to understand where and why individuals travel (Albayrak \& Caber, 2018; Wong et al., 2015; Wong et al., 2017; Yousefi \& Marzuki, 2012). In tourism and migration studies, the pull and push motivation model is accepted as the dominant paradigm. Essentially, this paradigm states that some negative factors in people's place of origin have a push effect, while positive factors in their destination of migration also have a pull effect (Bansal et al., 2005; Stimson \& Minnery, 1998).

In his study titled "A Theory of Migration," Lee (1966) addressed the factors that cause migration. According to this theory, both the place of origin and the destination have push and pull factors. It is accepted that there are four main factors related to migration in this theory: geographic origin, factors related to the geographic destination, intervening obstacles, and personal factors. According to Lee (1966), every act of migration involves an origin, a destination, and a set of intervening obstacles entering between these two. These three factors can be observed. For example, for most people, warm climate is a positive factor, while cold climate is a negative factor. However, some factors may be positive or negative according to the person's individual circumstances. Intervening obstacles refers to the obstacles in this process. These obstacles may be actual physical barriers to migration, as well as legal barriers such as migration legislation. Additionally, there are important personal factors in migration. These factors relate to individuals' personality traits, intellectual levels, knowledge of their origin and destination, and assessment approaches (Lee, 1966).

Haas and Serow (1993) revealed the amenity migration process model. In this model, various sources of information are influential, with push and pull factors taking an important role in the decision to migrate to a new destination (Carlson et al., 1998). In the light of past experiences (childhood home, a destination of a positive vacation experience, etc.), individuals make a decision to migrate by evaluating the factors that push them from the environment they live in and the pull factors that they will acquire through migration (climate, low living costs, low population, opportunity for a prosperous, higherquality life, etc.), together with their ideas and dreams. As a result of the experiences in the migratedto destination, in time, individuals' bond with that society increases. If what is thought and imagined before migration coincides with the facts, people continue to live there; otherwise, the decision to migrate is taken again, and the process returns to the beginning (Haas \& Serow, 1993).

Various studies in the literature have been reviewed to determine the main push and pull factors in migration, and some push and pull factors determined by evaluating the data obtained from these studies are presented in Table 1 . The obtained factors were grouped according to their qualities, and it was seen that these factors could be grouped under five categories. Research results acquired within the scope of amenity migration reveal that different push and pull motivation factors affect migration decisions. The results of the research on the subject are discussed in detail in the discussion section, along with the results of this research. 
Table 1. Push and Pull Factors of Amenity Migration

\begin{tabular}{|c|c|c|}
\hline Dimension & Push factors (origin) & Pull factors (destination) \\
\hline \multirow[t]{10}{*}{ Economic } & Bad economic conditions & Good economic conditions \\
\hline & Poor working conditions & Good working conditions \\
\hline & Low-income opportunities & High-income opportunities \\
\hline & Unemployment & Employment opportunities \\
\hline & Expensive living conditions & Cheap living conditions \\
\hline & Low level of welfare & High level of welfare \\
\hline & Real estate purchasing difficulties & Real estate purchasing opportunities \\
\hline & Famine & Abundance \\
\hline & Employment opportunities & Good retirement opportunities \\
\hline & Poor retirement opportunities & \\
\hline \multirow[t]{8}{*}{$\begin{array}{l}\text { Sociocultural } \\
\text { and political }\end{array}$} & $\begin{array}{l}\text { Discrimination (political, religious, ethnic, } \\
\text { other) }\end{array}$ & Equality (political, religious, ethnic, etc.) \\
\hline & Poor safety and security & High safety and security \\
\hline & Religious difficulty and pressures & Religious freedom \\
\hline & Political difficulties and pressures & Political freedom \\
\hline & Political instability & Political stability \\
\hline & Social tensions & Social peace \\
\hline & Government regulations/restrictions & Cultural attractions \\
\hline & & Social and cultural amenities \\
\hline \multirow[t]{6}{*}{ Environmental } & Ecological challenges & Ecological advantages \\
\hline & Declining natural resources & Abundant natural resources \\
\hline & Poor climatic conditions & Good climatic conditions \\
\hline & Desertification & $\begin{array}{l}\text { Physical environment and nature } \\
\text { opportunities }\end{array}$ \\
\hline & Natural disasters & Opportunities for outdoor recreation \\
\hline & Land shortage & \\
\hline \multirow[t]{12}{*}{ Personal } & Lack of personal development opportunities & Personal development opportunities \\
\hline & Health risks & Health opportunities \\
\hline & Being away from loved ones & Being with loved ones \\
\hline & Insufficient educational opportunities & Prospects for the future \\
\hline & Recreational inadequacies & Recreational facilities \\
\hline & Desire to get away/escape & Relaxing retirement \\
\hline & Feeling lonely & Social and physical activity opportunities \\
\hline & Concerns about crime & Adventure \\
\hline & Quality of medical care & Prestige \\
\hline & No close friends in the area & Rural life opportunities \\
\hline & Change in marital status & Good educational opportunities \\
\hline & Despair about the future & \\
\hline \multirow[t]{3}{*}{ Demographic } & Population growth and crowding & Crowd-free environment \\
\hline & Over-urbanization & Rural attractions \\
\hline & Traffic & Marriage \\
\hline
\end{tabular}

\section{Methodology}

Measures

A quantitative research methodology was adopted for the current study. The descriptive and explanatory research methods were used at the same time to achieve the objective of the research. In 
this context, descriptive research's aims are to determine amenity migrants' motivations within the push and pull motivation framework. Despite the increasing popularity of Turkey in terms of international amenity migration, there has been no study on foreigners' motivations to prefer Alanya. The second step in the research, which has an explanatory nature, attempts to determine the effect of push and pull motivation factors on destination satisfaction in the context of amenity migration by country.

The current study used questionnaires as a data collection tool. The questionnaire consisted of three sections. In the first section, there were questions to determine the participants' nationality, occupation, age, years of residence in Alanya, and preferred season to live in Alanya. In the context of amenity migration, the second part of the questionnaire included questions for determining the general destination satisfaction based on pull and push motivation factors that affect foreigners living in Alanya at a certain time of the year. The questions in the second part of the questionnaire were formed as a result of three stages. In the first stage, a draft scale was created by using the studies of Wong and Musa (2014, 2015), King et al. (2019), Casado-Diaz (2006), Carlson et al. (1998), Pickering et al. (2019), and Lipkina (2013). For the content validity of the scale, the opinions of five academicians who are experts in their fields were consulted. The content validity ratio and index were used to evaluate the expert opinions properly. As a result of the experts' content validity analysis, six items were removed from the draft scale. In the second stage, the scale, which was prepared in Turkish, was translated into English, German, Russian, and Arabic by advanced language users. Checking for consistency, the questionnaire was translated back into Turkish by professional translators. As a result of the cross-checks, it was observed that the questionnaire provided integrity of meaning and uniformity. In the third stage, a pretest study of the prepared scale in four different languages was carried out with 24 people from four different nationalities that were not included in the study sample. In the pre-test study, the question of "annual income" in the first part of the questionnaire was excluded from the final scale, as the majority of respondents did not want to respond to this question. As a result of the pre-test study, it was seen that all the items in the form were understood well. The third part of the questionnaire consisted of statements aimed at measuring destination satisfaction. The destination satisfaction scale consisting of three statements was adapted from Özyurt et al. (2018) and Yoon and Uysal (2005). The questionnaire items in the second and third parts were designed with a 7-point Likert-type scale, ranging from 1 (totally disagree) to 7 (totally agree). The research data were collected by a convenience sampling method with non-probability sampling techniques. The data were collected from April to November 2019 from the members of the Alanya Foreigners Assembly, members of foreign national associations in Alanya, and customers from five different real estate companies that sell houses to people of different nationalities. During the research, the questionnaire forms were distributed to 850 potential respondents, 507 of which were returned. Since 18 of them were not completely filled out, they were not evaluated, and as a result, the research data were obtained from 489 respondents.

\section{Data Analysis}

Before the research data could be analyzed, the suitability of the data to multivariate statistical studies was tested. Firstly, lost values, extreme outliers, and normal distribution were controlled for. No more than $5 \%$ data loss was detected in the data set, and these results showed there was no data loss. Next, extreme outlier analyses were carried out. Univariate outliers were evaluated with boxplots, and multivariate outliers were evaluated with Mahalanobis analysis. After the extreme outliers analysis, no extreme values could be determined. Multiple correspondence analysis was applied to better understand the similarities or differences of the participants according to their nationalities. Differences analysis was carried out. The effect of pull and push motivational factors on destination satisfaction in the context of country of origin was tested by hierarchical regression analysis. 


\section{Results}

\section{Sample Characteristics}

The research was conducted with the participation of 489 people. Table 2 contains the general characteristics of the participants in the research. Participants in the study were evaluated in three groups according to their country of origin. The first group consists of participants from different European countries (Denmark, Finland, France, Germany, Ireland, the Netherlands, Norway, Sweden, and the UK). This group is called "European Countries" and accounts for $42 \%$ of the total participants. The second group consists of participants who were citizens of the Russian Federation, making up 34\% of the total participants. The third group consists of participants from Middle Eastern countries such as Iraq, Jordan, Lebanon, Iran, and Kuwait. This group is named "Middle Eastern Countries" and accounts for $24 \%$ of the total participants.

Table 2. Description of the Participants $(n=489)$

\begin{tabular}{lll}
\hline \multicolumn{1}{l}{ Country Group } & $\mathrm{n}$ & $\%$ \\
European Countries & 206 & 42 \\
Russian Federation & 166 & 34 \\
Middle Eastern Countries & 117 & 24 \\
\hline Gender & & \\
Female & 157 & 32 \\
Male & 332 & 68 \\
\hline Age & & \\
$30-39$ & 119 & 24 \\
$40-49$ & 193 & 40 \\
50 years and over & 177 & 36 \\
\hline Occupation & & \\
Retired & 183 & 38 \\
Private Sector Employee & 99 & 20 \\
Self-employed & 207 & 42 \\
\hline Years of residence in Alanya & & \\
1-3 & 94 & 19 \\
$4-6$ & 147 & 30 \\
$7-9$ & 66 & 14 \\
10 years and over & 182 & 37 \\
\hline Preferred Season & & \\
Spring & 144 & 29 \\
Summer & 218 & 45 \\
Autumn & 127 & 26 \\
\hline
\end{tabular}

Multiple correspondence analysis (MCA) was applied to better understand how the main characteristics of the participants in the study were distributed according to their nationalities and these characteristics' similarities or differences according to the participants' nationalities. MCA is an explanatory multivariate analysis technique that transforms a data matrix into a special type of graphical representation. In MCA, the categorical data are shown on the graph so that the participants' similarities and differences are easily and accurately understood. According to the multiple correspondence analysis graph in Figure 1, it is understood that the basic characteristics of foreigners in Alanya in the context of amenity migration differ significantly according to nationality. In this context, it is indicated that people coming from European countries were retirees 50 years old and over, usually resided in Alanya during the autumn months, and had lived in Alanya for 10 years or longer. The newest and youngest group in Alanya was the citizens of Middle Eastern countries, who were in the 30-39 age group, 
had their own business in their country, had lived in Alanya for 1 to 3 years, and generally preferred to live in Alanya during the spring months. The participants who came to Alanya from Russia were in the 40-49 age group, had lived in Alanya for 5 years on average, and generally preferred the summer months; some of them had their own business in their country, and some were private-sector employees.

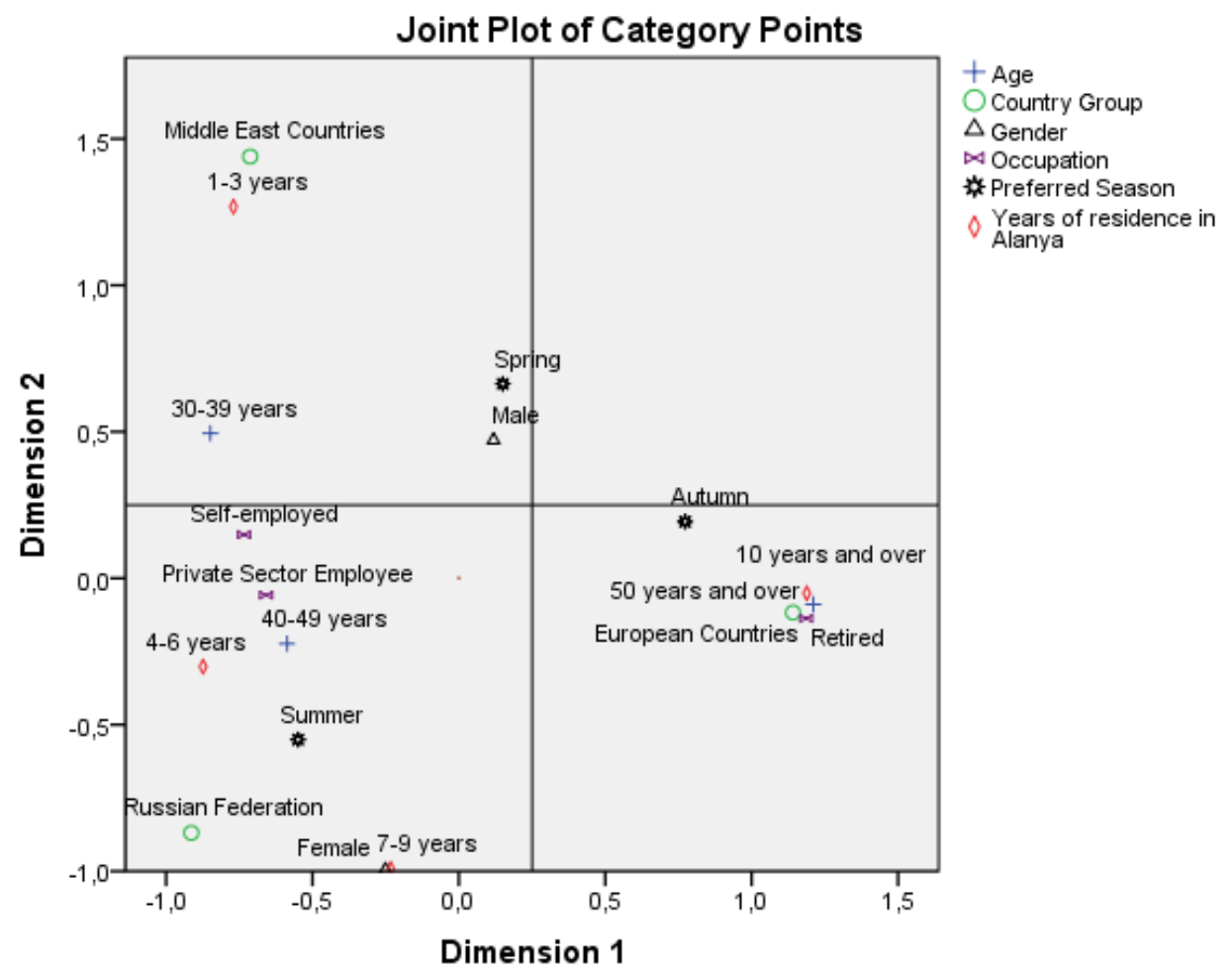

Variable Principal Normalization.

Figure 1. Characteristics of Foreigners Living in Alanya

In general, the oldest participants (50 years old and above) were from European countries, and the youngest participants (30-39 years) were from the Middle Eastern countries. It was determined that the occupations of the participants differed by their countries of origin. Participants from European countries constituted retirees, while participants from Middle Eastern countries and from Russia constituted persons who were self-employed in their country and those who work in the private sector in their country. In the current research, there were no participants from Russia or Middle Eastern countries who had retired and settled in Alanya. The duration of the participants' stay in Alanya differed according to their country. While the majority of participants from European countries had been living in Alanya for 10 years or more, participants from Russia and the Middle East had recently settled in Alanya. The participants' preferred season to reside in Alanya also differed by their nationality. Participants from European countries generally preferred to live in Alanya during the autumn months, while Russian participants mostly preferred to live in Alanya during the summer months, and participants from Middle Eastern countries preferred to live in Alanya during the spring months. 


\section{Convergent and Discriminant Validity}

Exploratory Factor Analysis

To achieve the first objective of this study, which was to identify amenity migrants' motivations, the items of the push and pull motivation were analyzed separately by exploratory factor analysis (EFA). In order to analyze the validity of the structure of the scale, EFA first examined the correlation matrix among all the items and checked whether there were significant correlations. The analysis results suggested that there were significant relationships that were suitable for factor analysis of items. The acquired Kaiser-Meyer-Olkin measure of sampling adequacy (KMO) values (Pull Factor=0.901; Push Factor $=0.898$ ) showed that the data were suitable for factor analysis (Hair et al., 2010). Bartlett's test of sphericity values (Pull Factor: $\chi^{2}(325)=10.372, p=0.000$; Push Factor: $\chi^{2}(153)=8.693, p=0.000$ ) were found to be statistically significant, indicating that significant factors or variables could be derived from the research data. As a result of the applied factor analysis, it was determined that the items under each factor on the scales were over 0.50 -factor load values. These findings suggest that the data could be subjected to factor analysis. An exploratory factor analysis of 26 pull motivation items was conducted, and eight factors were identified. These eight factors explained $69.91 \%$ of the total variance. Eighteen push motivation items were factor analysed, and six factors were obtained that explained $68.79 \%$ of the variance in motivation. The factors were named according to the items that they contained.

\section{Confirmatory Factor Analysis}

To ensure the validity of the measurement model, convergent and discriminant validity was evaluated by confirmatory factor analysis (CFA). While Exploratory Factor Analysis (EFA) provides information about the numbers of factors required to represent the data, in Confirmatory Factor Analysis (CFA) the number of factors required in the data can be specified and which measured variable is related to which latent variable (Castro \& Ferreira, 2018). According to the CFA results in Table 3, all standardized factor load values for the scale items were above 0.70 . All of the scale items had high $t$ values and were loaded into the corresponding latent variable in a statistically significant way $(\mathrm{p}<0.05)$. The goodness of fit statistics of the overall model $\left(\chi^{2}=1715,667, \mathrm{df}=725, \chi^{2} / \mathrm{df}=2,366, \mathrm{p}<0.000, \mathrm{RMSEA}=0.053, \mathrm{CFI}=0.951\right.$, $\mathrm{IFI}=0.952, \mathrm{NFI}=0.919, \mathrm{RFI}=0.904)$ suggest an acceptable model. Skewness and kurtosis values were calculated to determine the normality of distribution. The skewness and kurtosis values (between +1.5 and -1.5 ) for the scale items are in line with the assumption of multivariate normality (George \& Mallery, 2010).

Table 3. Overall Reliability of the Constructs and Factor Loadings of Indicators

\begin{tabular}{|c|c|c|c|c|c|c|}
\hline Pull Factors & $\begin{array}{l}\text { Standardized } \\
\text { Loadings }\end{array}$ & $\begin{array}{l}\text { Cronbach's } \\
\text { alpha }\end{array}$ & AVE & CR & MSV & ASV \\
\hline Factor 1: Affordable Cost & & 0.929 & 0.819 & 0.931 & 0.256 & 0.151 \\
\hline $\begin{array}{l}\text { Lower cost of host destination in comparison with an } \\
\text { alternative destination }\end{array}$ & 0.961 & & & & & \\
\hline Affordable housing price & 0.879 & & & & & \\
\hline Affordable cost in the host destination & 0.872 & & & & & \\
\hline Factor 2: Warm Climate and Local Culture & & 0.824 & 0.662 & 0.907 & 0.623 & 0.177 \\
\hline Warm climate in the host destination & 0.878 & & & & & \\
\hline Health issues related to climate & 0.852 & & & & & \\
\hline Sea, sand, sun & 0.809 & & & & & \\
\hline Friendly characteristics of the locals & 0.771 & & & & & \\
\hline Hospitality of local people & 0.751 & & & & & \\
\hline Factor 3: Healthcare and Medical Facilities & & 0.959 & 0.891 & 0.961 & 0.289 & 0.127 \\
\hline Easy access to health services & 0.974 & & & & & \\
\hline Adequate healthcare facilities & 0.965 & & & & & \\
\hline Quality of medical care & 0.891 & & & & & \\
\hline
\end{tabular}




\begin{tabular}{|c|c|c|c|c|c|c|}
\hline Factor 4: Ease of Transportation & & 0.887 & 0.725 & 0.887 & 0.393 & 0.234 \\
\hline Transportation opportunities for the city & 0.877 & & & & & \\
\hline Easy access all year round & 0.869 & & & & & \\
\hline Easy access by air & 0.806 & & & & & \\
\hline Factor 5: Amenities & & 0.878 & 0.710 & 0.880 & 0.116 & 0.016 \\
\hline $\begin{array}{l}\text { Sports, recreation, and cultural activities in the host } \\
\text { destination }\end{array}$ & 0.904 & & & & & \\
\hline Beautiful natural environments & 0.841 & & & & & \\
\hline $\begin{array}{l}\text { Accessibility of shopping malls, schools, sports } \\
\text { centers, etc. }\end{array}$ & 0.779 & & & & & \\
\hline Factor 6: Investment and Business Opportunities & & 0.896 & 0.743 & 0.897 & 0.387 & 0.293 \\
\hline Business contact opportunities & 0.884 & & & & & \\
\hline Business opportunities & 0.860 & & & & & \\
\hline Investment opportunities & 0.842 & & & & & \\
\hline Factor 7: Ease of Getting Residence & & 0.905 & 0.762 & 0.906 & 0.387 & 0.315 \\
\hline Ease of obtaining a visa & 0.879 & & & & & \\
\hline Ease of bureaucracy & 0.876 & & & & & \\
\hline Ease of purchasing housing for foreigners & 0.863 & & & & & \\
\hline Factor 8: Positive Holiday Experience & & 0.808 & 0.593 & 0.813 & 0.254 & 0.143 \\
\hline Positive vacation experience in the host destination & 0.811 & & & & & \\
\hline Comparisons of host destination to other destinations & 0.790 & & & & & \\
\hline Previous tourism experiences & 0.705 & & & & & \\
\hline Push Factors & $\begin{array}{l}\text { Standardized } \\
\text { Loadings }\end{array}$ & $\begin{array}{l}\text { Cronbach's } \\
\text { alpha }\end{array}$ & AVE & CR & MSV & ASV \\
\hline Factor 1: Cold Climate & & 0.911 & 0.851 & 0.945 & 0.623 & 0.200 \\
\hline The dream of living in a warm climate and by the sea & 0.950 & & & & & \\
\hline Cold climate & 0.931 & & & & & \\
\hline Health issues related to climate & 0.885 & & & & & \\
\hline Factor 2: Cost of Living & & 0.943 & 0.776 & 0.912 & 0.253 & 0.113 \\
\hline Economic conditions & 0.897 & & & & & \\
\hline Cost of living in the home county & 0.895 & & & & & \\
\hline High cost in the home destination & 0.850 & & & & & \\
\hline Factor 3: Environmental Conditions & & 0.916 & 0.829 & 0.936 & 0.560 & 0.257 \\
\hline Seeking a quiet life & 0.918 & & & & & \\
\hline Population density & 0.916 & & & & & \\
\hline Traffic congestion & 0.897 & & & & & \\
\hline $\begin{array}{l}\text { Factor 4: Political-Economic Instability and Social } \\
\text { Problems }\end{array}$ & & 0.945 & 0.859 & 0.948 & 0.465 & 0.259 \\
\hline Economic instability in the home country & 0.947 & & & & & \\
\hline Increasing social problems in the home country & 0.939 & & & & & \\
\hline Political instability in the home country & 0.894 & & & & & \\
\hline $\begin{array}{l}\text { Factor 5: Limited Business and Investment } \\
\text { Environment }\end{array}$ & & 0.956 & 0.880 & 0.956 & 0.383 & 0.211 \\
\hline Limited employment opportunities & 0.942 & & & & & \\
\hline Search for new investment opportunities & 0.938 & & & & & \\
\hline Seeking partnership & 0.934 & & & & & \\
\hline Factor 6: Health Problems & & 0.878 & 0.710 & 0.880 & 0.501 & 0.230 \\
\hline Spouse health issues & 0.880 & & & & & \\
\hline Getting away from a stressful environment & 0.831 & & & & & \\
\hline Personal health issues & 0.815 & & & & & \\
\hline
\end{tabular}

In order to test the structural validity and reliability of the scales, convergent validity and discriminant validity values needed to be examined, as well as the goodness of fit indices. Convergent validation points out that items related to variables are related to one another and the factor they constitute. The convergent validity, CR (construct reliability), and AVE (average variance extracted) values of the scales were calculated (Table 3). For convergent validity, all CR values for the scales are expected to be greater than the AVE values, and the AVE value is expected to be greater than 0.5. In the current study, the AVE 
and $C R$ values of the scales were found to be above 0.50 , and at the same time, the CR values were greater than the AVE values. These results reveal that the variables involved in the research have convergent validity. The MSV (maximum shared variance) and ASV (average shared variance) values are shown in Table 3 to test the discriminant validity of the scale. For discriminant validity, MSV and ASV values are expected to be lower than AVE values (Hair et al., 2010). When the MSV and ASV values in Table 3 are examined, it is seen that they are smaller than the AVE values. It is observed that the scale has convergent validity and discriminant validity within the framework of these obtained values.

\section{Push and Pull Motivations by Nationality}

One-way ANOVA was applied to determine whether the participants' motivational factors demonstrated a significant difference according to nationality. According to the one-way ANOVA results in Table 4, it is indicated that the participants' motivations differed significantly in terms of both pull and push factors by their country of origin. In terms of pull motivation factors, the most influential factors on European participants were "Warm Climate and Local Culture" (M=5.91) and "Positive Holiday Experience" (M=5.51), followed by "Healthcare and Medical Facilities" $(\mathrm{M}=5.17)$, "Ease of Transportation" $(M=5.08)$, and "Amenities" $(M=4.72)$. The "Cold Climate" $(M=6.13)$ factor, which includes issues such as health problems caused by climate and the desire to move away from a cold climate, was the strongest push motivator factor that influenced European participants' decision to come to Alanya in the context of welfare migration. Russian participants stated that all pull motivation factors except "Healthcare and Medical Facilities" $(\mathrm{M}=3.48)$ had an effect on their decision to come to Alanya. The most powerful push motivation factors that influenced the Russian participants' decision to come to Alanya were "Cold Climate" $(M=6.02)$, "Cost of Living" $(M=5.63)$, "Limited Business and Investment" (M=4.81), and "Political-Economic Instability and Social Problems" (M=4.77).

There are three main pull motivation factors that affected the decisions of the participants from the Middle Eastern countries to come to Alanya in the context of amenity migration: "Investment and

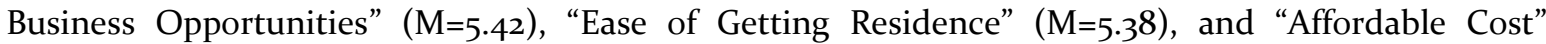
$(\mathrm{M}=5 \cdot 34)$. Alanya's investment opportunities and economic attractiveness and the fact that it is easier to obtain a visa there than other destinations constituted the strongest pull motivational factors for participants from Middle Eastern countries. The push motivation factors that had an effect on the Middle Eastern participants were "Political-Economic Instability and Social Problems" (M=5.74), "Limited Business and Investment Environment" $(\mathrm{M}=5.69)$, and "Cost of Living" $(\mathrm{M}=4,66)$ factors. These effective push factors are related to economic, social, and political issues, like the pull motivational factors.

Table 4. Pull and Push Motivational Differences Depending on Nationality

\begin{tabular}{|c|c|c|c|c|c|c|c|c|c|}
\hline \multirow[b]{2}{*}{ Pull Factors } & \multicolumn{2}{|c|}{$\begin{array}{l}\text { Europe } \\
\text { (a) }\end{array}$} & \multicolumn{2}{|c|}{$\begin{array}{l}\text { Russian } \\
\text { Federation (b) }\end{array}$} & \multicolumn{2}{|c|}{$\begin{array}{l}\text { Middle East } \\
\text { (c) }\end{array}$} & \multirow[t]{2}{*}{$\mathbf{F}$} & \multirow[t]{2}{*}{$\mathbf{p}$} & \multirow{2}{*}{$\begin{array}{l}\text { Post-Hoc } \\
\text { Tests }\end{array}$} \\
\hline & $\mathbf{M}$ & sd & $\mathbf{M}$ & sd & $\mathbf{M}$ & sd & & & \\
\hline Warm Climate and Local Culture & 5.91 & 0.399 & 5.96 & 0.437 & $3 \cdot 33$ & 0.685 & $739 \cdot 394$ & 0.000 & $\mathrm{a}^{\mathrm{c}}, \mathrm{b}^{\mathrm{c}}, \mathrm{c}^{\mathrm{a}, \mathrm{b}}$ \\
\hline Positive Holiday Experience & $5 \cdot 51$ & 0.431 & 5.14 & 0.82 & 4.09 & 0.899 & 153.388 & 0.000 & $\begin{array}{l}\mathrm{a}^{\mathrm{b}, \mathrm{c}}, \quad \mathrm{b}^{\mathrm{a}, \mathrm{c}}, \\
\mathrm{c}^{\mathrm{a}, \mathrm{b}}\end{array}$ \\
\hline Healthcare and Medical Facilities & 5.17 & 1.087 & 3.48 & 0.849 & 4.24 & 0.986 & $134 \cdot 978$ & 0.000 & $\begin{array}{l}\mathrm{a}^{\mathrm{b}, \mathrm{c}}, \quad \mathrm{b}^{\mathrm{a}, \mathrm{c}}, \\
\mathrm{c}^{\mathrm{a}, \mathrm{b}}\end{array}$ \\
\hline Ease of Transportation & 5.08 & 0.414 & 4.29 & 0.637 & 3.92 & 0.847 & 302.221 & 0.000 & $\begin{array}{l}\mathrm{a}^{\mathrm{b}, \mathrm{c}}, \quad \mathrm{b}^{\mathrm{a}, \mathrm{c}}, \\
\mathrm{c}^{\mathrm{a}, \mathrm{b}}\end{array}$ \\
\hline Amenities & 4.72 & 0.743 & 4.78 & 1.153 & 4.48 & 0.97 & 3.69 & 0.026 & $\mathrm{~b}^{\mathrm{c}}, \mathrm{c}^{\mathrm{b}}$ \\
\hline Affordable Cost & 3.92 & 1.156 & 5.2 & 1.286 & $5 \cdot 34$ & 0.809 & 83.713 & 0.000 & $a^{b, c}, b^{a}, c^{a}$ \\
\hline $\begin{array}{l}\text { Investment and Business } \\
\text { Opportunities }\end{array}$ & 3.05 & 0.637 & 4.97 & 0.722 & 5.42 & 0.57 & 636.777 & 0.000 & $\begin{array}{l}\mathrm{a}^{\mathrm{b}, \mathrm{c}}, \quad \mathrm{b}^{\mathrm{a}, \mathrm{c}} \\
\mathrm{c}^{\mathrm{a}, \mathrm{b}}\end{array}$ \\
\hline
\end{tabular}




\begin{tabular}{|c|c|c|c|c|c|c|c|c|c|}
\hline Ease of Getting Residence & 2.54 & 0.425 & 4.81 & 0.775 & 5.38 & 0.492 & 1138.853 & 0.000 & $\begin{array}{ll}\mathrm{a}^{\mathrm{b}, \mathrm{c}}, & \mathrm{b}^{\mathrm{a}, \mathrm{c}}, \\
\mathrm{c}^{\mathrm{a}, \mathrm{b}} & \end{array}$ \\
\hline Push Factors & m & sd & $\mathbf{m}$ & sd & m & sd & $\mathbf{F}$ & $\mathbf{p}$ & $\begin{array}{l}\text { Post-Hoc } \\
\text { Tests }\end{array}$ \\
\hline Cold Climate & 6.13 & 0.871 & 6.02 & 0.418 & 2.77 & 0.762 & 946.012 & 0.000 & $\mathrm{a}^{\mathrm{c}}, \mathrm{b}^{\mathrm{c}}, \mathrm{c}^{\mathrm{a}, \mathrm{b}}$ \\
\hline Environmental Conditions & 5.42 & 0.728 & 3.6 & 0.58 & $3 \cdot 3$ & 0.711 & 499.184 & 0.000 & $\begin{array}{l}a^{\mathrm{b}, \mathrm{c}}, \quad \mathrm{b}^{\mathrm{a}, \mathrm{c}}, \\
\mathrm{c}^{\mathrm{a}, \mathrm{b}}\end{array}$ \\
\hline Health Problems & 5.08 & 0.671 & 3.28 & 0.902 & 3.11 & 0.674 & 362.902 & 0.000 & $a^{b, c}, b^{a}, c^{a}$ \\
\hline Cost of Living & 3.98 & 0.794 & 5.63 & 0.727 & 4.66 & 0.774 & 211.687 & 0.000 & $\begin{array}{l}a^{\mathrm{b}, \mathrm{c}}, \quad \mathrm{b}^{\mathrm{a}, \mathrm{c}}, \\
\mathrm{c}^{\mathrm{a}, \mathrm{b}}\end{array}$ \\
\hline $\begin{array}{l}\text { Political-Economic Instability and } \\
\text { Social Problems }\end{array}$ & 3.36 & 0.94 & $4 \cdot 77$ & 0.601 & $5 \cdot 74$ & 0.926 & 326.589 & 0.000 & $\begin{array}{l}a^{\mathrm{b}, \mathrm{c}} \\
\mathrm{c}^{\mathrm{a}, \mathrm{b}}\end{array}$ \\
\hline $\begin{array}{l}\text { Limited Business and Investment } \\
\text { Environment }\end{array}$ & 2.99 & 1.051 & 4.81 & 1.249 & 5.69 & 0.994 & 251.21 & 0.000 & $\begin{array}{l}a^{\mathrm{b}, \mathrm{c}}, \quad \mathrm{b}^{\mathrm{a}, \mathrm{c}}, \\
\mathrm{c}^{\mathrm{a}, \mathrm{b}}\end{array}$ \\
\hline
\end{tabular}

\section{Push and Pull Motivations' Relationship with Destination Satisfaction}

The regression analysis results in Table 5 reveal that pull and push motivation factors have an effect on destination satisfaction in the context of country of origin. Motivational factors showed the strongest impact on overall destination satisfaction among the participants from Middle Eastern countries. Table 5 shows that $61.1 \%$ of the variance in overall destination satisfaction of Middle Eastern participants could be explained by their pull and push motivation factors $\left[\mathrm{F}_{(14-102)}=14.316 ; \mathrm{p}<0.05\right]$. Six motivation factors had an effect on destination satisfaction in the regression model. The most influential pull factors on destination satisfaction were (a) "Investment and Business Opportunities" ( $\beta=0.612)$, followed by (b) "Political-Economic Instability and Social Problems" $(\beta=0.483)$, (a) "Ease of Getting Residence" $(\beta=0.427)$, (b) "Limited Business and Investment Environment" ( $\beta=0.225)$, (a) "Ease of Transportation" $(\beta=0.193)$, and (b) "Health Problems" $(\beta=0.174)$.

Table 5. Influences of the Pull and Push Motivation on Destination Satisfaction Depending on Country of Origin

\begin{tabular}{|c|c|c|c|c|c|c|c|c|c|c|c|c|}
\hline & \multicolumn{4}{|c|}{ Northern Europe } & \multicolumn{4}{|c|}{ Russia } & \multicolumn{4}{|c|}{ Middle Eastern Countries } \\
\hline & B & SE & $\beta$ & $\mathbf{t}$ & $\mathbf{B}$ & SE & $\beta$ & $\mathbf{t}$ & B & SE & $\beta$ & $\mathbf{t}$ \\
\hline (Constant) & 3.030 & 1.653 & & 1.832 & 13.123 & 2.357 & & $5 \cdot 568^{*}$ & 9.238 & 1.723 & & $5 \cdot 361^{*}$ \\
\hline Ease of Getting Residence (a) & 0.048 & 0.119 & 0.022 & 0.398 & 0.006 & 0.093 & 0.005 & 0.066 & 0.940 & 0.141 & 0.427 & $6.649^{*}$ \\
\hline $\begin{array}{l}\text { Investment and Business } \\
\text { Opportunities (a) }\end{array}$ & 0.081 & 0.110 & 0.056 & 0.736 & 0.145 & 0.109 & 0.103 & 1.332 & 1.165 & 0.138 & 0.612 & $8.460^{*}$ \\
\hline $\begin{array}{l}\text { Healthcare and Medical } \\
\text { Facilities (a) }\end{array}$ & 0.066 & 0.066 & 0.078 & 0.996 & 0.162 & 0.091 & 0.136 & 1.775 & 0.116 & 0.089 & 0.105 & 1.296 \\
\hline Ease of Transportation (a) & 0.065 & 0.132 & 0.029 & 0.495 & 0.076 & 0.112 & 0.048 & 0.680 & 0.247 & 0.098 & 0.193 & $2.506^{*}$ \\
\hline Positive Holiday Experience (a) & 0.084 & 0.124 & 0.039 & 0.675 & 0.179 & 0.084 & 0.145 & $2.122^{*}$ & 0.080 & 0.078 & 0.066 & 1.018 \\
\hline Affordable Cost (a) & 0.039 & 0.059 & 0.050 & 0.673 & 0.149 & 0.062 & 0.190 & $2.396^{*}$ & 0.117 & 0.082 & 0.087 & 1.431 \\
\hline Amenities (a) & 0.023 & 0.074 & 0.018 & 0.304 & 0.185 & 0.073 & 0.212 & $2.542^{*}$ & 0.016 & 0.072 & 0.014 & 0.220 \\
\hline $\begin{array}{l}\text { Warm Climate and Local } \\
\text { Culture (a) }\end{array}$ & 1.165 & 0.133 & 0.506 & $8.739^{*}$ & 1.291 & 0.151 & $0.55^{8}$ & $8.565^{*}$ & 0.101 & 0.099 & 0.064 & 1.024 \\
\hline $\begin{array}{l}\text { Limited Business and } \\
\text { Investment Environment (b) }\end{array}$ & 0.003 & 0.057 & 0.003 & 0.048 & 0.225 & 0.061 & 0.278 & $3.687^{*}$ & 0.245 & 0.072 & 0.225 & $3.402^{*}$ \\
\hline $\begin{array}{l}\text { Political-Economic Instability } \\
\text { and Social Problems (b) }\end{array}$ & 0.069 & 0.055 & 0.070 & 1.251 & 0.488 & 0.126 & 0.291 & $3.868^{*}$ & 0.566 & 0.078 & 0.483 & $7.223^{*}$ \\
\hline Cold Climate (b) & 0.403 & 0.061 & 0.382 & $6.645^{*}$ & 0.610 & 0.185 & 0.252 & $3.294^{*}$ & 0.058 & 0.097 & 0.041 & 0.599 \\
\hline Cost of Living (b) & 0.035 & 0.069 & 0.030 & 0.507 & 0.126 & 0.089 & 0.091 & 1.422 & 0.113 & 0.093 & 0.081 & 1.216 \\
\hline Environmental Conditions (b) & 0.141 & 0.074 & 0.111 & 1.906 & 0.469 & 0.126 & 0.269 & $3 \cdot 721^{*}$ & 0.094 & 0.098 & 0.062 & 0.960 \\
\hline Health Problems (b) & 0.027 & 0.086 & 0.020 & 0.313 & 0.008 & 0.075 & 0.007 & 0.110 & 0.280 & 0.121 & 0.174 & $2.322^{*}$ \\
\hline & \multicolumn{4}{|c|}{$\begin{array}{l}R^{2}=0.481 \text { Ad. } R^{2}=0.443 \\
F=12.662 *\end{array}$} & \multicolumn{4}{|c|}{$\begin{array}{l}\mathrm{R}^{2}=0.454 \text { Ad. } \mathrm{R}^{2}=0.403 \\
\mathrm{~F}=8.951^{*}\end{array}$} & \multicolumn{4}{|c|}{$\begin{array}{l}R^{2}=0.663 \text { Ad. } R^{2}=0.616 \\
F=14 \cdot 316^{*}\end{array}$} \\
\hline
\end{tabular}

${ }^{*} \mathrm{p}<0.05$; (a) Pull Motivation Factor; (b) Push Motivation Factor 
Among European participants, $44.3 \%$ of the overall destination satisfaction was explained by pull and push motivation factors $\left[\mathrm{F}_{(14-191)}=12.662 ; \mathrm{p}<0.05\right]$. Pull and push motivation factors constituted $40.3 \%$ of their overall destination satisfaction. It was determined that there are two motivation factors that affected the destination satisfaction of European participants: (a) "Warm Climate and Local Culture" $(\beta=0.506)$ and (b) "Cold Climate" $(\beta=0.382)$. According to this result, it is suggested that European participants' destination satisfaction was completely affected by climate characteristics. Among Russian participants, $40.3 \%$ of destination satisfaction was explained by pull and push motivation factors $\left[\mathrm{F}_{\left(1^{-}-\right.}\right.$ $\left.{ }_{151}=8.951 ; \mathrm{p}<0.05\right]$. According to the results in Table 5, eight motivation factors had an effect on the Russians' satisfaction: (a) "Warm Climate and Local Culture" $(\beta=0.558)$, (b) "Political-Economic Instability and Social Problems $(\beta=0.291)$, (c) Limited Business and Investment Environment" $(\beta$ $=0.278)$, (d) "Environmental Conditions" $(\beta=0.269)$, (b) "Cold Climate $(\beta=0.252)$, (a) "Amenities" ( $\beta=0.212)$, (a) “Affordable Cost" $(\beta=0.19)$, and (a) "Positive Holiday Experience" $(\beta=0.145)$.

\section{Discussion}

Since the Second World War, European countries with a Mediterranean climate, such as Spain, Italy, and Portugal, have been frequently preferred in the context of amenity migration. In the 2ooos, countries like Turkey, Morocco, Thailand, and Malaysia started to become the preferred countries for amenity migration (King et al., 2019; Özerim, 2012). Bourdeau (2008) considered amenity migration as a subcategory of the post-tourism movement group. In a sense, tourism behavior paves the way for amenity migration. Migration researchers have revealed relationships between tourism and amenity migration (Williams et al., 200o). In this context, Turkey is one of the world's most important countries in terms of mass tourism destinations, and the number of tourists who choose Turkey is increasing every year. The constant preference of tourists who come to Turkey on a mass scale as a vacation destination has made them familiar with Turkey. At the same time, Turkey has made several legislative changes in line with the integration process into the European Union. In this context, especially in 2003, a large increase in foreigners' interest in Turkey was observed after the legal regulation that facilitated foreigners' purchasing of Turkish property (Südaş \& Mutluer, 2008). The process of migration starts after a tourist trip, then continues with purchasing a property in that region, and finally ends with settling on a seasonal or permanent basis. Understanding travel behavior is critical to the tourism sector.

Understanding behavior requires understanding the motivation of travel in a sense. Motivation and satisfaction issues constitute the basic structures of tourism behavior. It is therefore important to examine both motivations and satisfaction (Wong et al., 2017). Hence, the aim of this study was to determine the push and pull motivation factors of participants in the context of amenity migration and to empirically investigate the effect of motivation factors on destination satisfaction.

\section{Push and Pull Motivations of Amenity Migrants}

In terms of destination management and tourism marketing, it is very important to determine the factors that influence tourists' choice of destination (Hsu et al., 2009). Different motivational factors are encountered with regards to the reasons people turn to amenity migration (O'Reilly, 2007; Wong et al., 2017). Amenity migration, which is directly linked to tourism, differs due to both its causes and consequences and the demographics of migrants. This research's results showed that pull and push motivations dramatically change depending on the country of origin, at least in the context of amenity migration to Alanya. However, the research findings revealed that all pull and push motivation factors, albeit at different levels, had a strong effect on the participants' decision to choose Alanya. 
It was understood that the climate and culture motivation factor had a strong impact on the decisions of European and Russian participants to choose Alanya, while it did not have an impact on Middle Eastern participants. When the research on this subject is reviewed, it is seen that the climate and culture factor has an important effect on migration decisions. This finding on climate and cultural conditions coincides with the findings of the study of Casado-Diaz et al. (2004). A study of northern European migrants in the Costa del Sol, Spain's popular and populous tourist destination, concluded that migrants emigrated primarily because of their climate, then because of the Mediterranean way of life (rich cuisine, drinking, calm, and natural life) and healthy living. In a study on Spain, Algarve, Tuscany, and Malta on retiree migration in Europe, King et al. (1998) determined that climatic conditions strongly affected destination preference decisions. Rodriguez (2001) identified climatic conditions as the primary cause of migration in their study of retirement migration to Spain. Balkir et al. (2008) also concluded that the first reason retirees preferred Turkey was the climatic conditions in the Antalya sampling. Retirees believe that warm climates contribute positively to their health and that these climates enable them to participate in more social activities outside the home.

As a result of the research, it was determined that the positive vacation experience factor is an important pull motivation factor that affects the migration decision. Tourism experience plays an important role in migration decisions (Williams et al., 2000). Although tourism travel for entertainment and recreation is generally planned as a round trip, it may sometimes lead to re-visiting or buying a second residence as a result of satisfying one's environmental and spatial needs. Vacation satisfaction with the destination significantly affects the re-visiting of the destination (Kozak \& Rimmington, 2000). According to the findings obtained in the research, the positive vacation experience was a factor in amenity migration, especially for Europeans and Russians who had been on vacation in Alanya intensively since the 2000 . In a study by Williams et al. (200o) conducted on retirees who had migrated to Tuscany, Malta, Costa del Sol, and Algarve, retirees were associated with the places they had migrated to in the past for reasons of tourism, business, or family/childhood relationships. This finding suggests once again that the findings obtained are in line with the literature. In addition, in a study conducted by Nagatomo (2008), a significant relationship was found between tourism and decision-making in the migration of Japanese migrants from Japan to Austria.

Ease of transportation is particularly an important pull motivation for European participants while it is relatively important for participants from Russia and the Middle East countries. The sophistication of the transportation facilities plays a critical role in ensuring a town's connection to the world. It is not possible for unattractive and inaccessible tourism regions to be considered a sustainable product. Especially in the present day, when the concept of time and space has changed considerably, people want to easily and quickly reach places where they can spend enjoyable time. Especially, foreigners who settle in vacation villages want to spend a certain part of the year in their home countries and often travel to meet their families and relatives. Therefore, the improved transportation infrastructure of the town where they have settled is seen as a pull factor.

In this research, it was determined that the healthcare and medical facilities factor had a strong effect, principally on European participants' choice of Alanya. The healthcare and medical facilities factor is thought to be directly related to age, as the European participants also constituted the participants with the highest average age (50 years old and more). Health-related factors are often among the reasons that push or pull retirees to live abroad for a better life. It was stated that German retirees prefer the Canary Islands to eliminate existing diseases (Breuer, 2005). South Asian countries such as Singapore, Thailand, and Malaysia became the center of attraction for retirement migration, particularly with their investments in health tourism since the late 1990s (Gibler et al., 2009; Ono, 2008; Wong \& Musa, 2014). 
The pull factors of affordable cost, investment opportunities, and the ease of getting residence and the push factors of political-economic instability and social problems and limited business and investment opportunities were determined to have a strong influence on participants' choice of Alanya, especially that of Russians and Middle Easterners. This can be explained by the fact that these participants were young and because of their political and economic conditions. These motivation factors did not have a significant effect on European participants' preferences. Explanations from the literature include that immigrants from Europe decide to migrate primarily in search of comfort and amenities, and that economic reasons are pushed into the background (Breuer, 2005). However, there are also studies that show that the affordable cost factor also affects Europeans' migration decisions. Puzzo (2007) determined that British migrated to the quiet French countryside primarily to escape their busy lives. Additionally, it was revealed that the low cost of living in the region was an important factor on their migration decisions. Williams et al. (1997) revealed that there are three main reasons for retirement migration from Northern European countries to Southern European countries, first among which are economic factors, since the housing prices in Southern Europe are more affordable, and these countries have lower living costs.

\section{The Effect of Push and Pull Motivation Factors on Destination Satisfaction}

Motivation, an important determinant of tourism behavior, has been widely researched by academics since the 1940s. In particular, the motivation-satisfaction relationship has been a popular research interest of many academics because, in tourism and travel literature, motivation has been used as an effective variable of direct tourist satisfaction (Albayrak \& Caber, 2018). At the same time, destination satisfaction is the most important achievement of a destination (Yoon \& Uysal, 2005), however there is no consistency when measuring tourist satisfaction. Many studies gathered tourist evaluation of destination attributes to understand their satisfaction and/or destination performance (Nghiêm-Phu, 2017). The success and sustainable management of a destination depend on tourists' satisfaction with that destination (Rasoolimanesh, Jaafar, Marzuki, \& Abdullah, 2018). As a result, policymakers need to place a high emphasis on tourist satisfaction in order to successfully market a destination (Wong et al., 2017).

As a result of the research, it was determined that pull and push motivation factors positively affect destination satisfaction. However, the effects of pull and push motivation factors on destination satisfaction differ according to the country of origin. It was concluded that only climate- and culturerelated motivation factors affected the destination satisfaction of European participants. On the destination satisfaction of Middle Eastern participants, factors related to climate and culture had no significant effect. It was concluded that the motivational factors affecting the destination satisfaction of participants from Middle Eastern countries were mainly related to economic and political factors. It was determined that economics, politics, climate, culture, and amenities affected the destination satisfaction of Russian participants.

According to these results, the main factors affecting the destination satisfaction of Middle Eastern and Russian participants were based on the economic and political pull and push factors, while factors including climate and cultural dimensions affected the destination satisfaction of European participants. It was concluded that the push motivational factors of Middle Eastern and Russian participants had a higher impact on destination satisfaction than those of European participants. In a study on international retired migrants in Malaysia, Wong et al. (2017) determined that push and pull motivation factors had an effect on overall satisfaction. At the same time, Wong et al. (2017) found that push motivation factors had a stronger impact on the overall satisfaction. As a result of the research 
conducted by Carlson et al. (1998) on the factors affecting retirement migration to Idaho, it was determined that pull factors were more important than push factors in retirees' migration decisions.

\section{Conclusion}

According to the United Nations World Tourism Organization (UNWTO, 2019) and Ministry of Culture and Tourism Republic Turkey (MCT, 2020) statistics', Turkey is among the first ten countries in the world most tourist arrival. This data reveals that Turkey is an internationally popular tourism destination. Various studies revealing the relationship between tourism and amenity migration (Williams et al., 2000; Kuentzel \& Ramaswamy, 2005; Willams \& Gill, 2006; Ruiz-Ballesteros \& CaceresFeria, 2016) point out that popular tourist destinations have the potential to turn into amenity migration destinations over time. Alanya, as one of the tourist destinations most visited in Turkey, is moving towards becoming a popular destination in terms of amenity migration. In this research, it is aimed to analyse the push and pull motivation factors of foreigners from different nations residing in Alanya and to examine the relationships between their motivation factors and destination satisfaction.

It was determined that the motivation of the participants to choose Alanya differs according to their countries. As a result of the research, it has been determined that the factors related to climate, improved health services, positive holiday satisfaction experience previously spent in Alanya, ease of transportation, social and cultural activities are the factors that affect the decision of European participants to prefer Alanya. Moreover, pull factors such as affordable cost, investment opportunities, ease of obtaining a visa and push factors such as political economic instability and social problems, limited business and investment have been strong influence on participants from Russia and Middle East countries. In general, it is concluded that the motivation factors that affect the participants from Russia and Middle East countries to prefer Alanya are related to economic, social and political issues. Another intense result obtained in the study is related to the relationship between pull and push motivation factors and general destination satisfaction. According to the findings, pull and push motivation factors diversify according to the nationality and positively affect destination satisfaction. It was concluded that only climate and culture-related motivation factors were effective on the destination satisfaction of European participants. It has been determined that the motivation factors that affect the destination satisfaction of the participants from the Middle Eastern countries are mainly related to the economic and political factors. It has been detected that the factors of economic, political, climate, culture and amenity opportunities are effective on the destination satisfaction of the Russian participants.

\section{Managerial Implications and Limitations of Study}

In this study, the causes of amenity migration and destination satisfaction were evaluated using quantitative research methods in the context of push and pull factors. Although Alanya is a developing destination in terms of amenity migration in the Mediterranean region, it was seen that there had been a very limited number of studies about the region. In terms of destination management and tourism marketing, it is very important to specify the factors affecting tourists' destination selection (Hsu et al., 2009). Therefore, the study contributes to the literature about the Alanya region on a theoretical level. The study revealed valuable findings by addressing the destination preferences of individuals who come to Alanya within the framework of amenity migration in terms of push and pull factors. To this end, the research shows the importance of motivation, which is an effective force behind the behavior of amenity migration. The research also contributes to the literature in the fields of both geography and sociology in terms of addressing the reasons that people migrate towards amenities separately for each country. In particular, the findings of the relationship between push factors and destination satisfaction can provide practical contributions and ideas for local government policies to sustain the urban satisfaction 
of the migrants in Alanya. Tourism marketers and destination managers need to understand tourists' expectations, as competition is intensifying in the tourism sector. The research findings additionally reveal that destination management and marketing activities in the context of amenity migration should be conducted differently according to each country and culture. The results of this study provide useful information to policymakers, local governments, and especially businesses operating in the real estate and construction sector in designing effective destination management and marketing strategies. The limitation of this study is that the participants' motivations were considered only under the pull and push motivation theory. Other research can be carried out in the future with different theories of motivation.

\section{References}

Albayrak, T. \& Caber, M. (2018). Examining the relationship between tourist motivation and satisfaction by two competing methods. Tourism Management, 69, 20-213.

ALTSO (2019). Alanya Ekonomik Raporu. [Alanya Economic Report] https://www.altso.org.tr/wpcontent/uploads/2019/o9/altso-ekonomik-rapor-2018.pdf

Balkir, C. \& Kirkulak, B. (2007). Turkey as a new destination for retirement migration. In International migration, multi-local livelihoods and human security: Perspectives from Europe, Asia and Africa. The Netherlands: Institute of Social Studies.

Balkir, C., Karaman, Z. T. \& Kirkulak, B. (2008). Uluslararası Emekli Göçünün Sosyal ve Ekonomik Etkileri: Antalya Örneği. [The economic and social impact of international retirement migration: An empirical study on Antalya and its district] (pp. 39-65). Workshop Proceeding Book, Antalya.

Bansal, H.S., Taylor, S.F. \& James, Y. (2005). Migrating to new service providers: Toward a unifying framework of consumers' switching behaviors. Journal of the Academy of Marketing Science, 33(1), 96-115.

Benson, M.C. \& O’Reilly, K. (2009). Migration and the search for a better way of life: A critical exploration of lifestyle migration. The Sociological Review. 57(4), 6o8-625.

Borsdorf, A., Hidalgo, R. \& Zunino, H. (2012). Amenity migration: A comparative study of the Italian Alps and the Chilean Andes. Journal of Sustainability Education, 3(1), 1-10.

Bourdeau, P. (2008). Amenity migration and post-tourism. A geo-cultural approach to the alpine case. In: Moss, L.A.G., R.S. Glorioso \& A. Krause (eds.) Understanding and Managing Amenity-Led Migration in Mountain Regions. Banff, Alberta.

Breuer, T. (2005). Retirement migration or rather second-home tourism? German senior citizens on the Canary islands. Die Erde- Journal of the Geographical Society of Berlin, 136(3), 313-333.

Carlson, J.E., Junk, V.W., Fox, L.K, Rudzitisi, G. \& Cann, S.E. (1998). Factors affecting retirement migration to Idaho: An adaptation of the amenity retirement migration model. The Gerontolist, 38(1), 18-24.

Casado-Diaz, M.A. (2006). Retiring to Spain: An analysis of differences among North European nationals. Journal of Ethnic and Migration Studies, 32(8), 1321-1339.

Casado-Diaz, M.A., Kaiser, C. \& Warnes, A.M. (2004). Northern European retired residents in nine southern European areas: Characteristics, motivations and adjustment. Ageing and Society, 24(3), 353-381.

Castro, C. \& Ferreira, F. A. (2018). Entrepreneurs' self-perception of skills in rural tourism. European Journal of Tourism Research, 21, 50-68.

Chang, I., Liu, C. \& Chen, K. (2014). The push, pull and mooring effects in virtual migration for social networking sites. Information Systems Journal, 24(4), 323-346.

Commission of the European Communities. (1994). The demographic situation of the European Union: 1994 Report. Brussels: Commission of the European Union. 
Cuba, L. (1991). Models of migration decision making reexamined: The destination search of older migrants to Cape Cod. The Gerontologist, 31(2), 204-209.

Curry, G. N., Koczberski, G. \& Selwood., J. (2001). Cashing out, cashing in: Rural change on the South Coast of Western Australia. Australian Geographer, 32(1), 109-124.

EUC (2000). Push and pull factors of international migration a comparative report. Luxembourg: Office for Official Publications of the European Communities.

George, D. \& Mallery, M. (2010). SPSS for Windows Step by Step: A Simple Guide and Reference, Boston: Pearson.

Gibler, K.M., Casado-Diaz, J.M., Casado-Diaz, M.A., Rodriguez, V. \& Taltavull, P. (2009). Late life second move housing choices of international retiree migrants. International Journal of Housing Markets and Analysis, 2(2), 190-210.

Gustafson, P. (2008). Transnationalism in retirement migration: The case of North European retirees in Spain. Ethic and Racial Studies, 31(3),452-475.

Gustafson, P. (2013). Retirement migration. In. Ness, I. and Bellwood, P. (eds.). The Encyclopedia of Global Human Migration. Oxford: Blackwell Publishing.

Haas, W.H. \& Serow, W.J. (1993). Amenity retirement migration process: A model and preliminary evidence. The Gerontoogist, 33(2), 212-220.

Hair, J.F., Black, W.C., Babin, B.J. \& Anderson, R.E. (2010). Multivariate data analysis. New Jersey: Prentice Hall.

Hall, C.M. \& Müller, D. K. (2004) Introduction to second homes, curse or blessing? Revisited, In Hall, C.M., Müller, D.K. (eds.), Tourism, mobility and second homes between elite landscape and common ground, Clevedon: Channel View Publications.

Hazelrigg, L. E. \& Hardy, M. A. (1995). Older adult migration to the sunbelt. Research on Aging, 17(2), 209-234,

Hoggart, K. \& Buller, H. (1995). Geographical differences in British property acquisitions in rural France. The Geographical Journal, 161(1), 69-78.

Hsu, T. K., Tsai, Y. F. \& Wu, H. H. (2009). The preference analysis for tourist choice of destination: A case study of Taiwan. Tourism Management, 30, 288-297.

Kainth, G.S. (2010). Push and Pull Factors of Migration: A Case Study of Brick Kiln Migrant Workers in Punjab. MPRA Paper 30036, University Library of Munich, Germany

King, R., Cela, E., Morettini, G. \& Fokkema, T. (2019). The marche: Italy's new frontier for international retirement migration. Population Space and Place, 25(5), 1-12.

King, R., Warnes, A.M. \& Williams, A.M. (1998). International retirement migration in Europe. International Journal of Population Geography, 4(2), 91-111.

King, R., Warnes, T. \& Williams, A. M. (2000). Sunset lives: British retirement migration to the Mediterranean. Oxford: Berg publishers

Kozak, M. \& Rimmington, M. (200o). Tourist satisfaction with Mallorca, Spain, as an off-season holiday destination. Journal of Travel Research, 38(3), 260-269.

Kuentzel, W. F. \& Ramaswamy, V. M. (2005). Tourism and amenity migration a longitudinal analysis. Annals of Tourism Research, 32(2), 419-438.

Kummaraka, K. \& Jutaporn, R. (2011). The motivation of long-stay tourism and international retirement migration: Swedish in Thirees Thailand. portal.org/smash/get/diva2:424584/FULLTEXTo1.pdf

Lee, E.S. (1966). A theory of migration. Demography, 3(1), 47-57.

Lipkina, O. (2013). Motives for Russian second home ownership in Finland. Scandinavian Journal of Hospitality and Tourism, 13(4), 299-316.

Mason, P.A. (2002). Sunset lives: British retirement migration to the Mediterranean. Annals of Tourism Research, 29(2), 579-580. 
Massey, D.S., Arango, J., Hugo, G., Kouaouci, A., Pellegrino, A. \& Taylor, J.E. (1993). Theories of international migration: A review and appraisal. Population and Development Review, 19(3), 431466.

MasterCard. (2019). Global destination cities index. MasterCard International. https://newsroom.mastercard.com/wp-content/uploads/2019/o9/GDCI-Global-Report-FINAL1.pdf

McIntyre, N. (2009). Rethinking amenity migration: Integrating mobility, lifestyle and social ecological systems. Die Erde-Journal of the Geographical Society of Berlin, 140(3), 229-250.

MCT (2020). Tourism statistics. Ministry of Culture and Tourism Republic of Turkey. https://yigm.ktb.gov.tr/TR-9851/turizm-istatistikleri.html

Mitchell, C. (2004). Making sense of counterurbanization. Journal of Rural Studies, 20(1). 15-34.

Mook D. G. (1996). Motivation: The organization of action. (Second Edition), New York: W.W. Norton \& Company.

Moss, L. A. G. (2006). The amenity migrants: ecological challenge to contemporary Shangri-La. In: Moss, L. A. G. (ed.) The Amenity Migrants: Seeking and Sustaining Mountains and Their Cultures, Wallingford, UK and Cambridge, USA: CABI Publishing

Moutinho, L. (200o). Trends in tourism. In Moutinho, L. (eds.) Strategic management in tourism. CABI Pub, Wallingford, Oxon, UK ; New York, N.Y

Nagatomo, J. (2008). From tourist to migrant: The interaction between work-oriented lifstyle, tourism experience, and migration decision among Japanese lifestyle migrants to Australia. In A.M. Vicziany \& R. Cribb (Eds.), Proceedings of the 17th Biennial Conference of the Asian Studies Association of Australia.

Nam,V. \& Sato, M. (2010). Tourism development and amenity migration in hill stations: The case study of Sapa in Vietnam. Advanced Tourism Studies, 7, 1-22.

Nghiêm-Phu, B. (2017). Correlation between tourists' perceptions/evaluations of destination attributes and their overall satisfactions: Observations of a meta-analysis. European Journal of Tourism Research, 19, 98-115.

O’Reilly, K. (2007). Intra-European migration and the mobility-enclosure dialectic. Sociology, 41(2), 277293.

Ono, M. (2008). Long-stay tourism and international retirement migration: Japanese retirees in Malaysia. Senri Ethnological Reports, 77, 151-162.

Özerim, M.G. (2012). Emekli Göçleri Rotasında Türkiye: Avrupalı Emekli Göçmenlerin Türkiye'yi Tercih Etme Nedenleri ve Türkiye Algıları.[Turkey on the Route of Retirement Migration: The Motivations of European Retirement Migrants to Prefer Turkey and Their Perception of Turkey], Journal of Yasar University, 7(28), 4766- 4787.

Özyurt, P.M., Başaran, M.A. \& Kantarc1, K. (2018). Residential tourists' perceptions of quality of life: Case of Alanya, Turkey, Advances in Hospitality and Tourism Research, 6(2), 147-168.

Pickering, J., Crooks, V.A., Snyder, J. \& Morgan J. (2019). What is known about the factors motivating short-term international retirement migration? A scoping review. Population Ageing 12, 379-395.

Pitkänen, K. (2008). Second-home landscape: The meaning(s) of landscape for second-home tourism in Finnish Lakeland. Tourism Geographies, 10(2), 169-192.

Puzzo, C. (2007). British migration to the Midi-Pyrenees. In Geoffrey, C. \& Sibley, R. (Eds.) Going Abroad: Travel, Tourism, and Migration. Cross-cultural perspectives on Mobility. Newcastle, Cambridge Scholars Publishing.

Rasoolimanesh, S. M., Jaafar, M., Marzuki, A. \& Abdullah, S. (2018). Examining the effects of personal factors and travel characteristics on tourists' perceived crowding. European Journal of Tourism Research, 22, 5-19. 
Rodriguez, V., Mayorales, G. F. \& Rofo, F. (1998). European retirees on the Costa Del Sol: A crossnational comparison. International Journal of Population Geography, 4(2), 183-200.

Rodriguez, V. (2001). Tourism as a recruitinq post for retirement migration. Tourism Geographies, 3(1), 52-63.

Ruiz-Ballesteros, E. \& Caceres-Feria, R. (2016). Community-building and amenity migration in community-based tourism development. An approach from southwest Spain. Tourism Management, 54(2016), 513-523.

Sanchez, R. (2017). Leisure-tourism and amenity migration: Transformations observed in the semiarid mountain region of Northern Chile. Journal of Tourism and Cultural Change, 17(2), 150-165.

Segaran, R. R. K. \& Yahya, S. (2018). An analysis of push and pull factors motivating expatriate migrants to contemplate Malaysia as their second home: A conceptual paper. Journal of Business and Social Development, 6(1), 130-148.

Spalding A.K. (2013). Lifestyle migration to Bocas del Toro, Panama: exploring migration strategies and introducing local implications of the search for paradise. International Review of Social Research, 3(1), 67-86.

Stedman, R.C., Goetz, S.J. \& Weagraff, B. (2006). Does second home development adversely affect rural life? In W. A. Kandel \& D. L. Brown (Eds.), Population change and rural society (pp. 277-292). Netherlands: Springer.

Stewart, S.I. (2002). Amenity Migration. In Trends 2000: Shaping the Future-Proceedings of the $5^{\text {th }}$ Outdoor Recreation \& Tourism Trends Symposium, 17-20 September 2000 (Edited by Luft, K. and MacDonald S.), Lansing, Michigan.

Stimson, R.J. \& Minnery, J. (1998). Why people move to the 'sun-belt': A case study of long-distance migration to the Gold Coast. Australia, Urban Studies, 35(2), 193-214.

Sunil, T.S., Rojas, V. \& Bradley, D.E. (2007). United States' international retirement migration: The reasons for retiring to the environs of Lake Chapala, Mexico. Ageing \& Society, 27(4), 489-510.

Südaş, İ. \& Mutluer, M. (2010). Daha iyi bir hayata doğru: Yaşam biçimi göçü.[Towards a better life: Lifestyle migration]. Ege Coğrafya Dergisi, 19(1), 31-47.

Südaş, İ. \& Mutluer, M. (2008). Ekonomik etkileri açısından Türkiye'nin turizm merkezlerine yönelik Avrupalı göçleri. [European immigration towards Turkish tourism resorts: Economic impacts]. Ege Coğrafya Dergisi, 17(1-2), 51-59.

UNWTO (2019). World tourism barometer. United Nations World Tourism Organization, 18(1), doi.org/10.18111/wtobarometereng

Warnes, A. M., King, R., Williams, A.M. \& Patterson, G. (1999). The well-being of British expatriate retirees in southern Europe. Ageing and Society, 19(6), 717-740.

Williams, A., King, R., Warnes, A. M. \& Patterson, G. (2000). Tourism and international retirement migration: New forms of an old relationship in Southern Europe. Tourism Geographies: An International Journal of Tourism Space, Place and the Environment, 2(1), 28-49.

Williams, A. M., King, R. \& Warnes, A. M. (1997). A place in the sun: International retirement migration from Northern to Southern Europe. European Urban and Regional Studies, (4), 115-34.

Williams, P. W. \& A. M. Gill, A. M. (2006) A research agenda for tourism amenity migration destinations, Tourism Recreation Research, 31(1), 92-98.

Wong, K.M, Musa, G. \& Taha, A. Z. (2017). Malaysia my second home: The influence of push and pull motivations on satisfaction. Tourism Management, 61, 394-410.

Wong, K. M. \& Musa, G. (2014). Retirement motivation among 'Malaysia my second home' participants. Tourism Management, 40, 141-154.

Wong, K. M. \& Musa, G. (2015). International second home retirement motives in Malaysia: Comparing British and Japanese retirees. Asia Pacific Journal of Tourism Research, 20(9), 1041-1062. 
Yoon, Y. \& Uysal, M. (2005). An examination of the effects of motivation and satisfaction on destination loyalty: A structural model. Tourism Management, 26(1),45-56.

Yousefi, M. \& Marzuki, A. (2012). Travel motivations and the influential factors: The case of Penang, Malaysia. Anatolia: An International Journal of Tourism and Hospitality Research, 23(2), 169-176.

Received: 12/08/2020

Accepted: 29/11/2020

Coordinating editor: Stanislav Ivanov 